\title{
The antimicrobial efficacy of siwak (Salvadora persica) extract towards Streptococcus sanguis
}

\author{
Nurul Iradah Bohari*, Karlina Hardjawinata*, Indrati Sudjarwo* \\ *Department of Oral Biology Faculty of Dentistry Universitas Padjadjaran
}

\section{ABSTRACT}

Introduction: Siwak (Salvadora persica) has been used for good oral hygiene maintenance purposes by the Babylonians since 7000 years ago and also by the Greek, Roman, Egyptian, and Arabian. The aim of this study is to assess the antimicrobial efficacy of siwak extract towards Streptococcus sanguis as the oral-plaque-inducer, by determining the Minimum Inhibitory Concentration (MIC) and exposure time, to determine whether siwak extract could be chosen as an alternative ingredient for plaque control. Methods: Type of research is experimental laboratory. The MIC test were conducted based on a serial dilution of $64 \%, 32 \%, 16 \%, 8 \%, 4 \%, 2 \%, 1 \%, 0.5 \%, 0.25 \%$, and $0.125 \%$ concentration of siwak extract respectively, against 5 samples of Streptococcus sanguis within three repetitions. The exposure time test has been performed within 30 seconds, 1', 2', 3', and 4' with $0.25 \%, 0.5 \%$, and $1.0 \%$ concentration of siwak extract. Results: The siwak extract can inhibit Streptococcus sanguis at the concentration of $0.25 \%$ to $0.125 \%$. There is no antimicrobial effect towards Streptococcus sanguis until 4 minutes of exposure time. Conclusion: Siwak extract had the antimicrobial effect towards Streptococcus sanguis in minimum concentration between $0.25 \%-0.125 \%$ with the exposure time more than 4 minutes.

Keywords: Antimicrobial efficacy, siwak (Salvadora persica) extract, Streptococcus sanguis.

\section{INTRODUCTION}

Dental plaque is a dense bacterial mass, also known as biofilm, that is tightly adherent to the tooth surface ${ }^{1}$ The initial colonies of plaque are primarily commensal microbes such as streptococci especially Streptococcus sanguis which are also the normal oral micro-flora.1,2 Dental plaque is the major etiology of periodontal diseases and is related to dental caries. ${ }^{2}$ The European Workshop on Mechanical Plaque Control (1998) had concluded that the effective removal of dental plaque is essential to dental and periodontal health throughout life. The first step of plaque control is the prevention of plaque formation. Inhibition of the formation of dental plaque can be done by inhibiting the growth of the plaque inducer bacteria, which is Streptococcus sanguis.

Salvadora persica, known as the toothbrush tree or locally known as siwak, is a member of Salvadoraceae family. The use of siwak has been known since many centuries ago, especially by the ancient Arabians. It is still being used until now as an oral hygiene tool. The beneficial effects of Salvadora persica in respect of oral hygiene and dental health are due to its mechanical and chemical actions. ${ }^{3}$ 
A study of Al-Lafi and Ababneh reported that siwak contains natural minerals that can kill and inhibit bacterial growth, eroded plaque, prevent cavities and care for the gum. ${ }^{4}$ Siwak has useful chemical contents, including antibacterial agents such as benzyl-isothiocyanate, alkaloid, trimethylamine, fluoride, silica and resin. They acted as antimicrobial agent, astringent, abrasive and detergent that kills bacteria, prevents infection, and stops gums bleeding. ${ }^{3}$ Siwak is also stimulates saliva production, which itself is organic saliva that protects and cleans the mouth. ${ }^{5}$

Nowadays, through technological innovation, siwak stick has been changed into powder and blended into toothpaste. However, a further study needs to be done as additional information and knowledge on the effectiveness of siwak as an antimicrobial agent for plaque control. The effectiveness of siwak extract as an antimicrobial agent will be tested towards Streptococcus sanguis based on the Minimum Inhibitory Concentration (MIC) and exposure time. The aim of this study is to assess the antimicrobial efficacy of siwak extract towards Streptococcus sanguis as the oral-plaque-inducer, by determining the Minimum Inhibitory Concentration (MIC) and exposure time, to determine whether siwak extract could be chosen as an alternative ingredient for plaque control.

\section{METHODS}

This study is an in-laboratory experimental research. The antimicrobial efficacy of siwak (Salvadora persica) extract towards Streptococcus sanguis based on the MIC and the exposure time are the main purpose of this study.

Streptococcus sanguis samples were obtained and isolated from the saliva of ${ }^{5}$ dental students of Universitas Padjadjaran. Samples were taken by asking students to spit into the petri dish. The mixed culture from the saliva was then discreted and cultured on blood agar plate (BAP) by using the streak plate method.

Extraction of siwak was done in the Pharmacy Laboratory, Faculty of Pharmacy, Universitas Padjadjaran by the maceration method.

Isolation of pure culture is done to ensure that bacteria used in this study is Streptococcus sanguis alone. After 24 hours of incubation, characteristic examination of these bacteria was done.

The MIC test was done to determine the lowest level of concentration of siwak extract that is needed to inhibit the growth of Streptococcus sanguis based on serial dilution method and by using 10 test tubes. One $\mathrm{ml}$ of Streptococcus sanguis suspension was added into the test tube 1 to 10 , and test tube 12 with bacterial turbidity corresponding

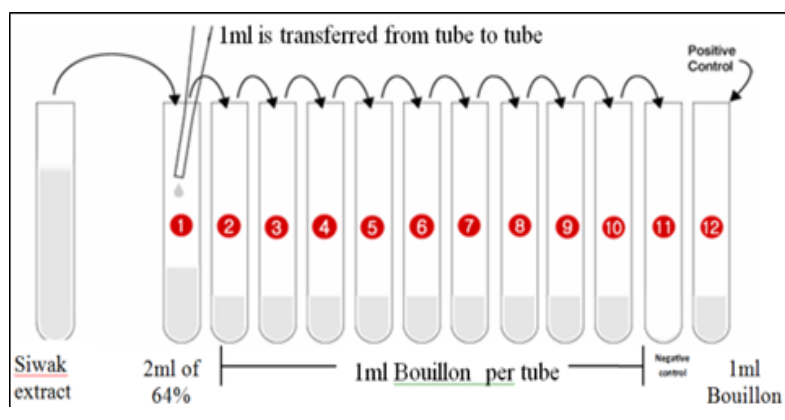

Figure 1. Serial Dilution Test Tubes

Table 1. Serial Dilution of Siwak Extract

\begin{tabular}{|c|c|c|c|c|c|}
\hline Test tube & $\begin{array}{l}\text { Bouillon } \\
(\mathrm{ml})\end{array}$ & $\begin{array}{l}\text { Siwak } \\
\text { solution }\end{array}$ & Dilution & $\begin{array}{l}\text { Siwak } \\
(\%)\end{array}$ & $\begin{array}{l}\text { Mc } \\
\text { Farland } \\
(\mathrm{ml})\end{array}$ \\
\hline 1 & - & $2 \mathrm{ml}$ & 1 & 64 & 0.1 \\
\hline 2 & 1 & $\begin{array}{l}1 \mathrm{ml} \\
\text { from test } \\
\text { tube } 1\end{array}$ & 2 & 32 & 0.1 \\
\hline 3 & 1 & $\begin{array}{l}1 \mathrm{ml} \\
\text { from test } \\
\text { tube } 2\end{array}$ & 4 & 16 & 0.1 \\
\hline 4 & 1 & $\begin{array}{l}1 \mathrm{ml} \\
\text { from test } \\
\text { tube } 3\end{array}$ & 8 & 8 & 0.1 \\
\hline 5 & 1 & $\begin{array}{l}1 \mathrm{ml} \\
\text { from test } \\
\text { tube } 4\end{array}$ & 16 & 4 & 0.1 \\
\hline 6 & 1 & $\begin{array}{l}1 \mathrm{ml} \\
\text { from test } \\
\text { tube } 5\end{array}$ & 32 & 2 & 0.1 \\
\hline 7 & 1 & $\begin{array}{l}1 \mathrm{ml} \\
\text { from test } \\
\text { tube } 6\end{array}$ & 64 & 1 & 0.1 \\
\hline 8 & 1 & $\begin{array}{l}1 \mathrm{ml} \\
\text { from test } \\
\text { tube } 7\end{array}$ & 128 & 0.5 & 0.1 \\
\hline 9 & 1 & $\begin{array}{l}1 \mathrm{ml} \\
\text { from test } \\
\text { tube } 8\end{array}$ & 256 & 0.25 & 0.1 \\
\hline 10 & 1 & $\begin{array}{l}1 \mathrm{ml} \\
\text { from test } \\
\text { tube } 9\end{array}$ & 512 & 0.125 & 0.1 \\
\hline 11 & - & $\begin{array}{l}1 \mathrm{ml} \\
\text { from test } \\
\text { tube } 10\end{array}$ & $\mathrm{NC}$ & 0.125 & 0.1 \\
\hline
\end{tabular}


with McFarland standard 0.5. McFarland standards were used as a reference to adjust the turbidity of bacterial suspensions so that the number of bacteria will be within a given range. ${ }^{6}$ Test tube 11 is left as a negative control (Figure 1). The lowest concentration of the siwak extract showing inhibition toward bacterial growth is the MIC.

A specific procedure was done to know the exposure time of the antimicrobial agent to the suspension of microorganism that is effective to inhibit bacterial growth. Incubated culture for 24 hours of Streptococcus sanguis at $370 \mathrm{C}$ in facultative anaerobic that was standardized based on McFarland 0.5 standard is pipetted for $0.1 \mathrm{ml}$ and then put in the test tubes contain MIC $(0.25 \%), 2 \times M I C(0.5 \%)$ and 4 XMIC $(1.0 \%)$ of siwak extract. They were agitated until homogeny was reached. After being left to contact for 30 seconds, it was streaked on the first quadrant of BAP. After 1 minute, the solution was streaked again on the second quadrant of the same BAP. Streaking of the solution on third and fourth and fifth quadrant was done after contact of the solution at 2 minutes, 3 minutes and 4 minutes respectively (Figure 3 ). The specimens were then incubated under a facultative anaerobic condition at $370 \mathrm{C}$ for 24 hours. When there was the least amount of bacterial growth on the BAP on the least time of exposure, it was said that it was the most effective time of exposure needed for bacterial growth inhibition.

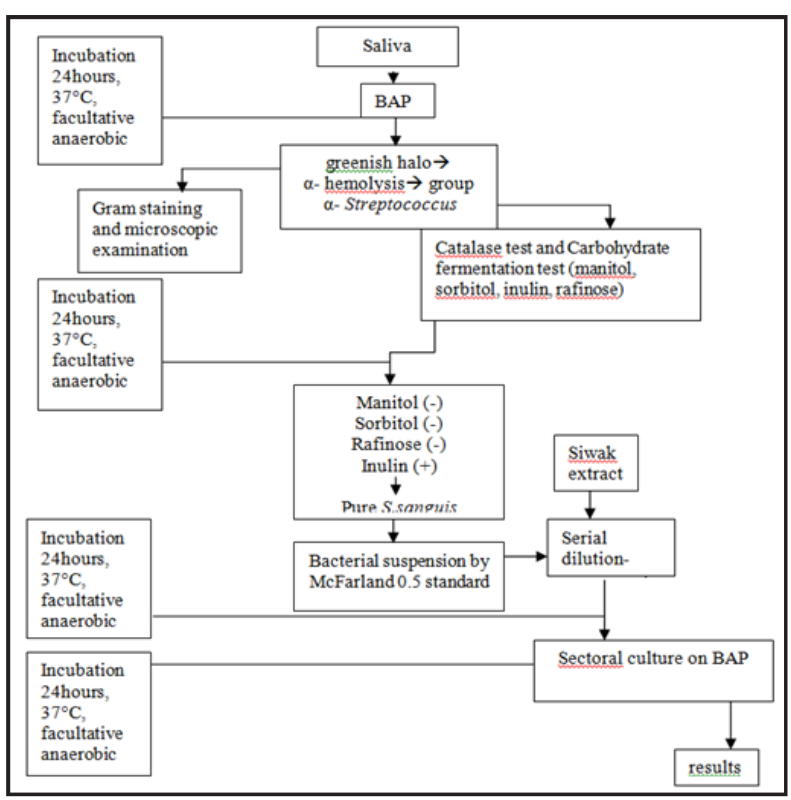

Figure 2. Steps sequence chart

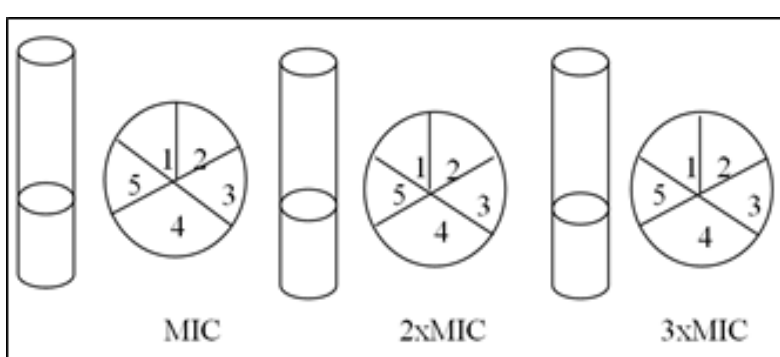

Figure 3. Incubated Streptococcus sanguis in serial dilution test tubes

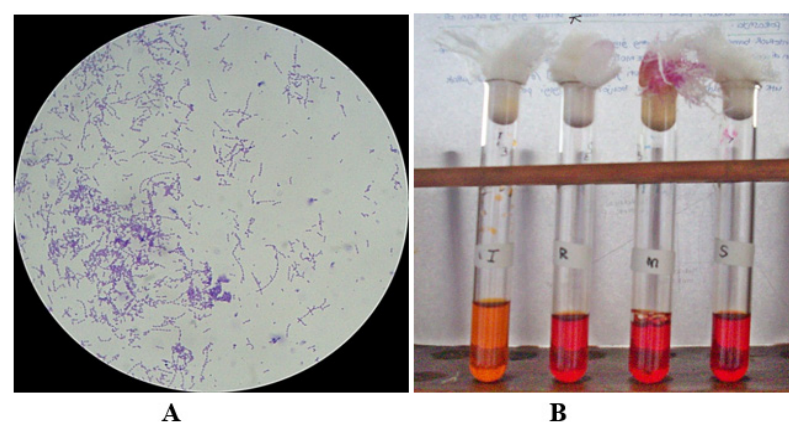

Figure 4.A: Streptococcus sanguis and B: Biochemical Identification

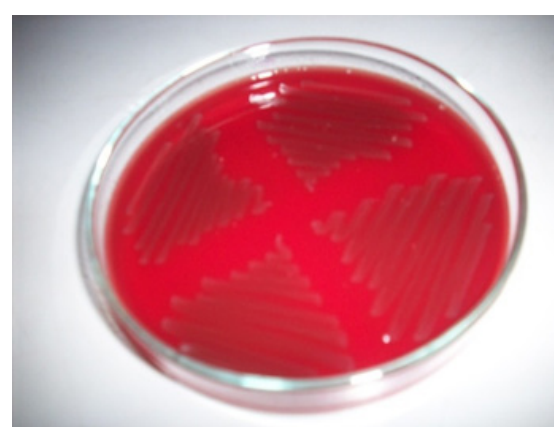

Figure 5. Colonies of Streptococcus sanguis in Sectoral Culture

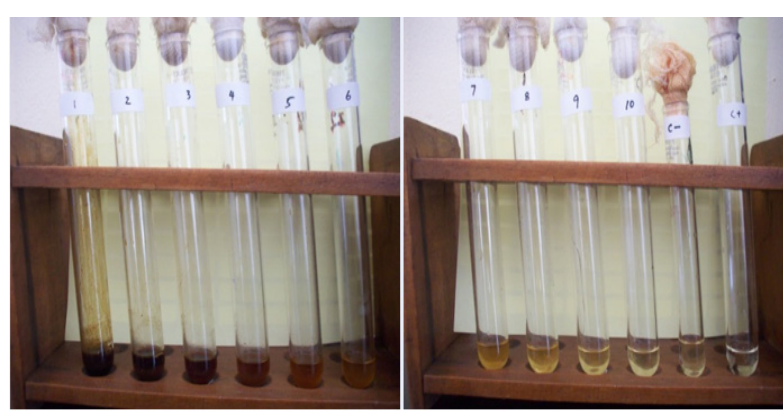

Figure 6. Incubated Streptococcus sanguis in serial dilution test tubes

Notes: Concentration of siwak extract in test tubes:

$\begin{array}{lllll}1 & : 64 \% & 6 & : 2 \% & C(-): \text { Negative control } \\ 2 & : 32 \% & 7 & : 1 \% & C(+) \text { : Positive control } \\ 3 & : 16 \% & 8 & : 0.5 \% & \\ 4 & : 8 \% & 9 & : 0.25 \% & \\ 5 & : 4 \% & 10 & : 0.125 \% & \end{array}$


using the Gram staining. This examination showed Gram-positive cocci in chains (Figure 1A). Besides, it can maintain the purple color of crystal violet although hit as been washed with 95\% alcohol and was given the fuchsin dye. Hence the colonies can be suspected as the Streptococcus species.

There were no gas bubbles formed in the catalase test, so the reaction is negative,

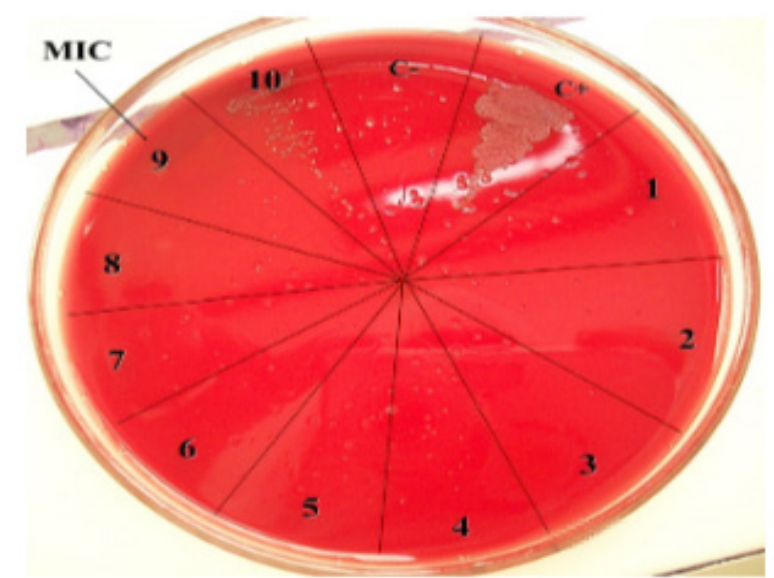

Figure 7. Determination of MIC based on Sectoral Culture of Streptococcus sanguis on BAP

Notes: Concentration of siwak extract in sector:

$\begin{array}{llll}: 64 \% & 6 & : 2 \% & C(-): \text { Negative control } \\ : 32 \% & 7 & : 1 \% & C(+) \text { : Positive control } \\ : 16 \% & 8 & : 0.5 \% & \\ : 8 \% & 9 & : 0.25 \% & \\ : 4 \% & 10 & : 0.125 \% & \end{array}$

meaning the suspected bacteria can be proved as Streptococcus but not Staphylococcus. ${ }^{7}$

In biochemical identification test, the culture of bacteria in a medium containing red phenol indicator from mannitol, sorbitol and raffinose did not show any change of color where the solutions remain red. Hence, the test result is negative otherwise. In inulin culture, there were color changes of the indicator from red to yellow, so positive test results are stated (Figure 4B). Hemodigestive colonies that give result like these

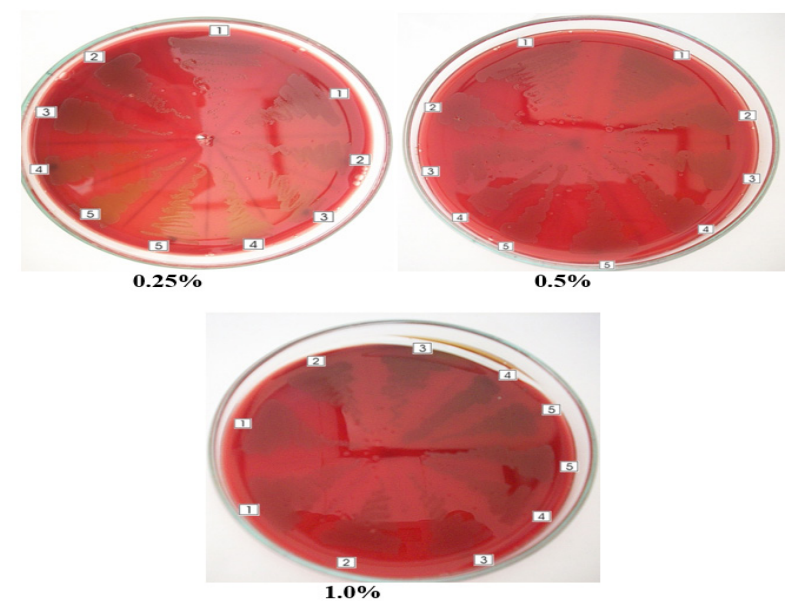

Figure 8. Sectoral Culture of Streptococcus sanguis on Blood Agar Plate in Different Concentration of Siwak extract and Different Exposure Times

Notes: Sector 1: $30 \mathrm{sec}, 2: 1 \mathrm{~min}, 3: 2 \mathrm{~min}, 4: 3 \mathrm{~min}, 5: 4 \mathrm{~min}$

Table 2. Sectoral Culture of Streptococcus sanguis on Blood Agar Plate in Different Concentrations of Siwak extract

\begin{tabular}{|c|c|c|c|c|c|c|c|c|c|c|c|c|c|c|c|c|}
\hline \multirow[t]{2}{*}{ Siwak extract concentration } & \multicolumn{16}{|c|}{ Exposure time (minute) with 3 times repetition } \\
\hline & Sample & & $1 / 2$ & & & 1 & & & 2 & & & 3 & & & 4 & \\
\hline \multirow[t]{5}{*}{ MIC } & 1 & + & + & + & + & + & + & + & + & + & + & + & + & + & + & + \\
\hline & 2 & + & + & + & + & + & + & + & + & + & + & + & + & + & + & + \\
\hline & 3 & + & + & + & + & + & + & + & + & + & + & + & + & + & + & + \\
\hline & 4 & + & + & + & + & + & + & + & + & + & + & + & + & + & + & + \\
\hline & 5 & + & + & + & + & + & + & + & + & + & + & + & + & + & + & + \\
\hline \multirow[t]{5}{*}{$2 \times M I C$} & 1 & + & + & + & + & + & + & + & + & + & + & + & + & + & + & + \\
\hline & 2 & + & + & + & + & + & + & + & + & + & + & + & + & + & + & + \\
\hline & 3 & + & + & + & + & + & + & + & + & + & + & + & + & + & + & + \\
\hline & 4 & + & + & + & + & + & + & + & + & + & + & + & + & + & + & + \\
\hline & 5 & + & + & + & + & + & + & + & + & + & + & + & + & + & + & + \\
\hline \multirow[t]{5}{*}{$4 \times M I C$} & 1 & + & + & + & + & + & + & + & + & + & + & + & + & + & + & + \\
\hline & 2 & + & + & + & + & + & + & + & + & + & + & + & + & + & + & + \\
\hline & 3 & + & + & + & + & + & + & + & + & + & + & + & + & + & + & + \\
\hline & 4 & + & + & + & + & + & + & + & + & + & + & + & + & + & + & + \\
\hline & 5 & + & + & + & + & + & + & + & + & + & + & + & + & + & + & + \\
\hline
\end{tabular}

Notes: MIC: $0.25 \%$; 2 MIC: $0.5 \%$; 4xMIC: $1.0 \%$; - shows no bacterial growth of Streptococcus sanguis; +: shows bacterial growth of Streptococcus sanguis 
were diagnosed as Streptococcus sanguis. ${ }^{8}$

MIC of macerated siwak extract towards Streptococcus sanguis The result from the incubated Streptococcus sanguis in serial dilution test tubes did not show clear turbidity differences because of being interrupted by the dark color of the siwak extract itself (Figure 3). Results by sectoral culture in BAP showed no bacterial growth of Streptococcus sanguis in sector 1 to 9 as in sector 11 , which is the negative control. The growth of the colony began in sector ten as in sector twelv which is the positive control. (Figure 4). Three times repetition of the test for the five samples of Streptococcus sanguis gave the same results (Table 2).

It means that the MIC of siwak extract towards Streptococcus sanguis is between the concentration of test tube 9 and 10 which are $0.25 \%$ and $0.125 \%$ siwak extract concentrations. Exposure time of Siwak extract towards Streptococcus sanguis. Based on MIC test results, exposure time test is done on MIC $(0.25 \%), 2 \times M I C$ $(0.5 \%)$, and $4 \times \mathrm{MIC}(1.0 \%)$ at exposure time of 30seconds, 1 minute, 2 minutes, 3 minutes, and 4 minutes (Figure $5 \&$ Table 3). Notes: Sector 1: 30sec, 2: $1 \mathrm{~min}, 3: 2 \mathrm{~min}, 4: 3 \mathrm{~min}, 5: 4 \mathrm{~min}$. The three times repetition of experiment showed the same results (Table 3 ).

\section{DISCUSSION}

After 24-hours incubation under a facultative anaerobic condition in $37 \mathrm{oC}$, bacteria cultured on BAP showed small circle-shaped colonies that were surrounded by green halo zone which signifies the Streptococcus species. The bacteria can partially lyse the $\mathrm{Hb}$ in blood to metHb. This is what caused the green halo zone can be seen. The green halo zone indicates Streptococcus group viridans also known as a-hemolytic Streptococcus. ${ }^{9}$

Gram staining and examination under 10x100 magnification microscope reveal chains of coccus bacteria that was purple. It was defined as the Gram-positive bacteria because Gram-positive bacteria's cell wall has a thicker peptidoglycan layer compared to Gram-negative bacterias. lodine, which functions as a mordant, retains the purple color of crystal violet that has been absorbed by the bacteria's cell wall. Therefore, after decolorization with alcohol, Gram-positive bacteria remains purple, whereas Gram-negative become colorless because the fuchsin dye dissolved by alcohol and escape out of bacterial cell walls. ${ }^{10,1}$

Streptococcus species do not produce catalase that converts $\mathrm{H} 2 \mathrm{O} 2$ into water and oxygen, in the catalase test where the $\mathrm{H} 2 \mathrm{O} 23 \%$ were dropped on bacterial suspension, there were no gas bubbles produced. This indicates negative result which proves that the suspected bacteria is not Staphylococcus species. ${ }^{10}$

Carbohydrate fermentation test of inulin results in changes of red color to yellow because the suspected bacteria can ferment inulin to produce acid. It is the acid that changes the red color indicator to become yellow. There are no color changes of carbohydrate fermentation test of raffinose, mannitol and sorbitol as the suspected bacteria did not ferment those sugar alcohol. In this test, changes of red color indicator to yellow is interpreted as a positive result and vice versa, therefore it can be concluded that the suspected bacteria is Streptococcus sanguis. ${ }^{10}$

In this study siwak (Salvadora persica) were used in the extracted form. Therefore it can be easily manipulated and diluted to a specific concentration required. Extraction is the withdrawal of chemical composition that can be dissolved. It can be separated from another component that cannot be dissolved by the liquid solvent. ${ }^{12}$

In minimum inhibitory concentration test, the determination of the MIC was difficult because the incubated Streptococcus sanguis in serial dilution test tubes didn't show clear turbidity differences as it was being interrupted by the dark color of the siwak extract itself. That is why the sectoral culture of solution from all the test tubes on blood agar plates (BAP) was done to ascertain the growth of bacteria from each concentration and more definite results can be obtained.

Streptococcus sanguis is sensitive towards $64 \%, 32 \%, 16 \%, 8 \%, 4 \%, 2 \%, 1 \%$, and $0.5 \%$ siwak extract concentration. These show the high antimicrobial effect of siwak extract towards Streptococcus sanguis as the bacteria can only grow in the very low concentration of siwak extract which is $0.25 \%$. Studies have suggested that the ability of siwak to inhibit bacteria is may be due to the various chemical composition that 
contains in its extract such as alkaloid, tannins, and trimethylamine, but information on the mechanism of action contributing to the reported antibacterial effects of siwak is relatively limited.

In fact, the inhibition of bacterial growth may be attributed to the large amount of benzylisothiocyanate (BITC) in siwak approximately $70 \% .5$ (Sofrata, 2010). It has been suggested that the possible enzymatic action of saliva on siwak isothiocyanate may release unstable products that exert antimicrobial activity in vivo. ${ }^{13}$ In a clinical trial, Gazi et al. found a significant increase in the salivary calcium and chloride levels with a significant decrease in $\mathrm{pH}$ of saliva and phosphate immediately after chewing siwak. ${ }^{14}$ The authors also showed that dental plaque and gingival bleeding indices were significantly lower after immediate use of siwak in comparison with the immediate use of the conventional toothbrush. The anionic compound in BITC which is thiocyanate $(\mathrm{SCN}-)$ is a substrate for lactoperoxidase to generate hypothiocyanite ( $\mathrm{OSCN}-$ ). SCN- from siwak together with low salivary $\mathrm{pH}$ may enhance the bacteriocidal activity of nitrate against cariogenic bacteria. Rosin et al. (2001) claimed that a dentifrice containing $0.5 \% \mathrm{SCN}$ - and $0.1 \%$ $\mathrm{H} 2 \mathrm{O} 2$ inhibited dental plaque and gingivitis. ${ }^{15,16}$

Moreover, OSCN- play the role as an antimicrobial compound that responsible for the damage of oral bacteria. It can inhibit the growth and acid production of a variety of oral microorganism including Streptococci, Lactobacilli, and fungi by oxidizing bacteria enzymes in the glycolytic pathway that contain sensitive thiol groups. At the low $\mathrm{pH}, \mathrm{OSCN}$ - becomes protonated to form the hypothiocyanous acid ( $\mathrm{HOSCN})$, and because it is uncharged, can rapidly pass through the cell wall and cytoplasmic membrane to the cytosol. 1 These will lead to disturbance and might be the destruction of bacteria organelles hence inhibits the cell metabolism.

However, the antimicrobial effect of siwak extract can only be seen in exposure time of 24 hours. There was no inhibition growth of Streptococcus sanguis in exposure time until 4 minutes, which are the reasonable length of time usually needed by an individual to brush teeth or rinse mouth. These might be due to traditionally siwak is used by its twig which is $100 \%$ pure siwak concentration and generally for a longer period than is the modern toothbrush. The cleaning is usually implemented for 5 to 10 minutes. ${ }^{17}$

The MIC of siwak extract towards Streptococcus sanguis is between $0.25 \%$ to $0.125 \%$ siwak extract concentration and the exposure time needed by siwak extract concentration of $0.25 \%, 0.5 \%$ and $1 \%$ to inhibit the growth of Streptococcus sanguis is more than 4 minutes. Therefore, further study should be conducted with a pure concentration of siwak extract in higher exposure time so the beneficial effect of siwak can be exploit and siwak can be applied as oral hygiene maintenance tools.

\section{CONCLUSION}

Siwak extract had the antimicrobial effect towards Streptococcus sanguis in minimum concentration between $0.25 \%-0.125 \%$ with the exposure time more than 4 minutes.

\section{REFERENCES}

1. Lamont R. J., Lantz M. S., Burne R. A., Leblanc D. J. 2006. Oral Microbiology and Immunology, American Society for Microbiology, Washington DC, 53-55, 119, 253.

2. Carranza, F.A and M.G Newman. 2006. Glickman's Clinical Periodontology 10th edition. Philadelphia: W.B. Sounders Co, 141143, 728.

3. Almas, K. 1999. Miswak . A Cultural and Scientific Heritage, Saudi Dental Journal. Vol 21-3.

4. Al-Lafi T. and Ababneh H. 1995. The effect of the extract of the miswak (chewing sticks) used in Jordan and the Middle East on oral bacteria. Int Dent J;45:218-22.

5. Sofrata A.A. 2010. Salvadora persica (Miswak), An effective way of killing oral pathogens, from the Division of Periodontology, Department of Dental Medicine, Karolonska Institute, Stockholm, Sweden.

6. Goldman E., Green L. H. 2009. Practical Handbook of Microbiology, 2nd Ed., Taylor \& Francis Group. LLC, 16-17.

7. Lennette, E.H. 1985. Manual Clinical Microbiology.ed 4 Washington DC: American Society for Microbiology, 967-987.

8. Holt, J.G., N.R. Krieg, P.H. Sneath, J.T. Staley 
and S.T. Williams. 1994. Bergeysmanual of Determinative Bacteriology, 9th Ed. Williams and Wilkins, London, UK.

9. Shimeld L. A. 1999. Essential of Diagnostic Microbiology, Delmar Publishers. 124-125.

10. Capuccino, James G., Natalie Sherman, 2001, Microbiology : A Laboratory Manual, Soxth Edition, Benjamin Cummings, San Fransisico.

11. Direktorat Jenderal Pengawasan Obat dan Makanan. Parameter Standar Umum Ekstrak Tumbuhan Obat. Ed. 1. Jakarta: Departmen Kesehatan, 2000.

12. Direktorat Jenderal Pengawasan Obat dan Makanan. Parameter Standar Umum Ekstrak Tumbuhan Obat. Ed. 1. Jakarta: Departmen Kesehatan, 2000.

13. Elvin-Lewis M. 1982. The therapeutical potential of plants used in dental folk medicine. Odontostomatol Trop. 3:107-17.

14. Gazi MI, Davies TJ, al-Bagieh N, Cox SW. 1992. The immediate- and mediumterm effects of Meswak on the composition of mixed saliva. J Clin Periodontol. 19:113-7.

15. Rosin $M$, Welk A, Bernhardt $O$, Ruhnau $M$, Pitten FA, Kocher T, Kramer A. 2001. Effect of a Polyhexamethylene Biguanide Mouthrinse on Bacterial Counts and Plaque. J Clin Periodontol. 28: 1121-1126.

16. Rosin M, Kocher T, Kramer A. 2001. Effects of $\mathrm{SCN}-/ \mathrm{H} 2 \mathrm{O} 2$ combinations in dentifrices on plaque and gingivitis. $\mathrm{J} \mathrm{Clin} \mathrm{Periodontol.}$ 28:270-6.

17. Akhtar MS, Ajmal M. 1981. Significance of chewing-sticks (miswaks) in oral hygiene from a pharmacological viewpoint. J Pak Med Assoc. 31:89-95. 